\title{
Effect of Plant Growth Regulators on Growth, Yield and Quality of Strawberry (Fragaria $\times$ ananassa Duch.) cv. Winter Dawn in the Gangetic Alluvial Region of West Bengal, India
}

\author{
Tanushree Saha*, Bikash Ghosh, Sanjit Debnath, \\ Subhasis Kundu and Ajoy Bhattacharjee \\ Department of Fruit Science, Bidhan Chandra Krishi Viswavidyalaya, \\ Mohanpur, Nadia 741252, West Bengal \\ *Corresponding author
}

\begin{abstract}
A B S T R A C T
The present investigation was carried out during 2016-17 and 2017-18 at Bidhan Chandra Krishi Viswavidyalaya to study the effect of different plant growth regulators (PGRs) on growth, yield and quality of strawberry (Fragaria $\times$ ananassa Duch.) cv. Winter Dawn, grown under shade net. The experiment was laid out in RBD, replicated 3 times with nine treatments, viz., $\mathrm{GA}_{3}$ (20 and $40 \mathrm{ppm}$ ), NAA (20 and $40 \mathrm{ppm}$ ), Cycocel (500 and 750 ppm), BA (25 and $50 \mathrm{ppm}$ ) and Control (water spray), applied as foliar spray at 15 and 30 DAP. Significant differences were observed with respect to growth, yield and quality of strawberry. The results revealed that, application of $\mathrm{GA}_{3} @ 40$ ppm significantly improved vegetative growth, flowering, fruiting parameters over control, while Cycocel @ 750 ppm resulted in earlier flower initiation (29.36 vs. 43.13 days) and improved fruit weight (24.05 vs. $17.78 \mathrm{~g}$ ). However, $\mathrm{GA}_{3} @ 40 \mathrm{ppm}$ resulted in significantly highest productivity (2.68 t/ha) and fruit quality in terms of TSS $\left(6.48{ }^{\circ}\right.$ Brix), TSS:acid ratio (10.29), ascorbic acid $(57.35 \mathrm{mg} / 100 \mathrm{~g}$ pulp) and anthocyanin content $(65.68 \mathrm{mg} / 100 \mathrm{~g}$ pulp). The estimated benefit: cost ratio (B:C) was highest (2.92:1) for $\mathrm{GA}_{3} @ 40$ ppm, followed by $\mathrm{GA}_{3} @ 20$ ppm (2.63:1). From this study, foliar spray of $\mathrm{GA}_{3} @ 40 \mathrm{ppm}$ at 15 and 30 days after planting was recommended as cost-effective treatment for improvement of plant growth, productivity and fruit quality of strawberry grown in the Gangetic alluvial region of West Bengal.
\end{abstract}

\section{Introduction}

The cultivated octaploid strawberry (Fragaria $\times$ ananassa Duch.), having chromosome no. $2 n=8 x=56$, an aggregate fruit, of the family Rosaceae, is one of the most luscious refreshing soft fruits of the world.
Strawberries are rich in natural anti-oxidants (Wang et al., 1996). Earlier, strawberry cultivation in India was confined to only the temperate regions like Jammu and Kashmir, Himachal Pradesh, but in recent years, development of new varieties adaptable to wide range of climatic condition and 
standardization of new agro-techniques has resulted in strawberry cultivation in nontraditional provinces of India (Sharma and Sharma, 2004). Presently, strawberry is cultivated throughout India in an area of 0.6 thousand hectares producing 4.3 thousand metric tons for local consumption as well as for export purpose (Anon, 2018). Strawberry cultivation is gaining popularity in the Gangetic alluvial zone of West Bengal, however, its marketing and profit are suffering due to lack of desired quality and size of fruit. Plant growth regulators (PGRs) have proven their regulatory role in various facets of plant growth and developmental processes, which in turn induce vegetative and reproductive growth responses and enhance production efficiency (Basra, 2000). Keeping in view the need to enhance the strawberry production, marketability and profit margin, the present investigation was planned to find out the optimum concentration of plant growth regulators and its effect on fruit size, yield and quality of strawberry fruits and production economics.

\section{Materials and Methods}

The present investigation on the effect of plant growth regulators on growth, yield and quality of strawberry (Fragaria $\times$ ananassa Duch.) cv. Winter Dawn was carried out during 201617 to 2017-18 at Bidhan Chandra Krishi Viswavidyalaya, Mohanpur, Nadia under shade net condition. The experimental field was situated at $23.5^{\circ} \mathrm{N}$ latitude and $89^{\circ} \mathrm{E}$ longitude with an elevation of $9.75 \mathrm{~m}$ above mean sea level. The experimental area belongs to sub-tropical humid climate under Gangetic new alluvial plains of West Bengal. The soil texture of the experimental field was alluvial in nature and sandy loam in texture, having $64.8 \%$ sand, $10.4 \%$ silt and $24.8 \%$ clay, $\mathrm{pH}-$ 6.96 , organic carbon- $0.51 \%$, available $\mathrm{N}$ $175.61 \mathrm{~kg} / \mathrm{ha}$, available $\mathrm{P}_{2} \mathrm{O}_{5^{-}} 26.06 \mathrm{~kg} / \mathrm{ha}$, available K- $76.27 \mathrm{~kg} / \mathrm{ha}$. The experiment was laid out in Randomized Block Design (RBD), replicated thrice, having plot size $4 \mathrm{~m} \times 1 \mathrm{~m}$, accommodating 28 tissue cultured plants (variety Winter Dawn) in each bed with a spacing of $45 \mathrm{~cm} \times 30 \mathrm{~cm}$ between the rows and plants, leaving a space of $0.45 \mathrm{~m}$ between different beds for better crop management. The plants were dipped in Bavistin solution (1 $\mathrm{g} / \mathrm{l})$ before planting. The double row planting of the one month old plants was done in the month of November. Black polythene mulch (300 gauge thickness) was applied at the time of planting. Nine treatments viz., $\mathrm{T}_{1}-\mathrm{GA}_{3} @$ 20 ppm; $\mathrm{T}_{2}-\mathrm{GA}_{3} @ 40$ ppm; T -NAA @ 20 ppm; T 4 -NAA @ 40 ppm; T5-Cycocel @ 500 ppm; T6-Cycocel@750 ppm; T7-BA @25 ppm; $\mathrm{T}_{8}$-BA @ 50 ppm; $\mathrm{T}_{9}$-Control as water spray only were imposed for two times at 15 and 30 days after planting (DAP). Well decomposed farmyard manure @ 5 t/ha and Vermicompost @ 500 kg/ha were incorporated uniformly into the soil 20 days before planting. N: P: K @ 100:80:100 kg/ha were applied 10 days before planting. Fungicides like, Bavistin@1g/1 and Blitox@ 3g/l and insecticides like Confidor @ 0.33 $\mathrm{ml} / \mathrm{l}$ and Dursban @ 3 ml/l were sprayed simultaneously at 15 days interval. Statistical inference of the data was obtained following the analysis of variance (ANOVA) for Randomized Block Design (RBD) (Gomez and Gomez, 1984).

\section{Results and Discussion}

\section{Vegetative parameters}

Results presented in table 1 showed significant increase in response to different plant growth regulators as compared to control $\left(\mathrm{T}_{9}\right)$ plants throughout the period of investigation. Maximum plant height $(18.33 \mathrm{~cm})$ and plant spread $(37.30 \mathrm{~cm})$ were recorded with $\mathrm{GA}_{3}$ @ 40 ppm $\left(\mathrm{T}_{2}\right)$, which was followed by $\mathrm{GA}_{3} @$ $20 \mathrm{ppm}\left(\mathrm{T}_{1}\right)$ treatment $(16.37 \mathrm{~cm}$ plant height and $35.62 \mathrm{~cm}$ spread). However, the minimum 
plant height $(10.71 \mathrm{~cm})$ and plant spread $(27.83 \mathrm{~cm})$ were recorded in plants sprayed with Cycocel @ 750 ppm $\left(\mathrm{T}_{6}\right)$. It had significantly lower plant height and spread than control $\left(\mathrm{T}_{9}\right)$ treatment $(11.84 \mathrm{~cm}$ height and $28.39 \mathrm{~cm}$ spread). The application of $\mathrm{GA}_{3}$ @ $40 \mathrm{ppm}$ produced the maximum petiole length $(16.47 \mathrm{~cm})$ and number of shoots/plant (20.89), number of leaves/plant (23.29), while minimum petiole length $(9.24 \mathrm{~cm})$ and number of shoots/plant (14.21), number of leaves/plant (13.19) was observed due to application of Cycocel @ 750 ppm. The increase in plant height, spread, petiole length, number of leaves, leaf area and number of shoots of strawberry cv. Winter Dawn with the spray of $\mathrm{GA}_{3}$ in the present study might be due to the fact that gibberellins regulate the growth of strawberry plants by causing cell division, cell elongation and a corresponding increase in epidermal and parenchyma's cell length (Turner, 1963 and Guttridge and Thompson, 1959). The increase in cell elongation with the application of $\mathrm{GA}_{3}$ might be due to increased synthesis of auxin in the strawberry plant system (Singh and Phogat, 1983). Maximum leaf area $\left(121.12 \mathrm{~cm}^{2}\right)$ and number of runners/plant (5.23) were observed in case of plants treated with $\mathrm{GA}_{3} @ 40$ ppm $\left(\mathrm{T}_{2}\right)$, whereas, minimum leaf area $\left(98.31 \mathrm{~cm}^{2}\right)$ and number of runners/plant (1.85) were observed in case of control plants $\left(\mathrm{T}_{9}\right)$.

The present findings on better vegetative growth following gibberellic acid spray are in line with the results obtained by Sharma and Singh (1990), Kumar et al., (2012), Saima et al., (2014). Application of cycocel significantly reduced the plant height, spread during the study period. Cycocel being a growth retardant and has anti-gibberellin activity i.e., inhibition of cell division and cell elongation in sub-apical meristems which is known to reduce vegetative growth in strawberry cultivars. These results are in agreement with the earlier findings of Saima et al., (2014).

\section{Reproductive parameters}

The data on flowering and fruiting parameters viz., duration of flowering, fruit setting and fruit maturity, number of flowers/plant, fruit set $\%$, number of fruits/plant presented in Table 2. These reproductive parameters showed significant variations due to application of plant growth regulators. The application of Cycocel@ 750 ppm $\left(\mathrm{T}_{6}\right)$ effectively influenced earlier flower initiation (29.36 days), earlier fruit set (4.29 days), days required from fruit set to fruit maturity (15.55 days), which was followed by Cycocel @ 500 ppm $\left(\mathrm{T}_{5}\right)$ treatment (31.77 days, 4.50 days and 15.72 days, respectively). However, number of flowers/plant (27.16), fruit set \% $(78.05 \%)$ and number of fruits/plant (21.23) were recorded maximum in plants treated with $\mathrm{GA}_{3}$ @ 40 ppm $\left(\mathrm{T}_{2}\right)$ and was followed by $\mathrm{GA}_{3} @$ $20 \mathrm{ppm}\left(\mathrm{T}_{1}\right)$. Higher number of fruits under $\mathrm{GA}_{3} @ 40$ ppm treatment might be due to the fact that Gibberellic acid causes the production of large number of flowers with rapid elongation of peduncle, leading to full development of flower buds having all reproductive parts functional and accumulate higher starch, carbohydrates and photosynthates which increases the fruit set and number of berries per plant. It could also be due to the fact that GA application accelerated the development of differentiated inflorescence. The present results are in conformity with the earlier findings of Saima et al., (2014) in strawberry.

An inquisition of the data in the study revealed that application Cycocel@ 750 ppm resulted in maximum fruit weight $(24.05 \mathrm{~g})$ and volume $(17.73 \mathrm{cc})$ of fruits, but application of $\mathrm{GA}_{3} @ 40$ ppm maximize fruit yield (470.15 $\mathrm{g} / \mathrm{plant})$ and productivity (2.68 tonnes/ha) (Table 3). Increase in yield with $\mathrm{GA}_{3}$ might have been due to the greater photosynthesis and the movement of photosynthates and nutrient into the developing fruit. These 
results are in agreement with Anwar et al., (1990). The increase in length, diameter, weight and volume of berries with the application of Cycocel might be due to greater supply of photosynthates to the reproductive growth than the vegetative growth and also due to lower percentage of fruit set and lower number of fruits which enables fruit growth to its maximum extent. This is in close conformity with the findings of Rajesh et al., (2012) in strawberry crop.

\section{Fruit quality parameters}

The observations recorded on fruit quality such as total soluble solids (TSS), acidity, ascorbic acid (vitamin C) and anthocyanin content of fruit indicated that application of plant growth regulators significantly improved the fruit quality parameters, with respect to increased TSS, ascorbic acid content, anthocyanin content, but reduced the acidity percentage of fruit as compared to control (Table 4). Application of $\mathrm{GA}_{3} @ 40$ ppm $\left(\mathrm{T}_{2}\right)$ recorded highest total soluble solids content (6.48 ${ }^{0}$ Brix), TSS/acid ratio (10.29), total sugar $(5.66 \%)$ and reducing sugar $(4.20 \%)$, ascorbic acid (57.35 mg/100 g pulp) and anthocyanin content $(65.68 \mathrm{mg} / 100 \mathrm{~g}$ pulp$)$ of fruit. The minimum titratable acidity $(0.61 \%)$ was recorded in $\mathrm{T}_{2}$ treatment $\left(\mathrm{GA}_{3} @ 40\right.$ $\mathrm{ppm})$. The increase in TSS by the application of $\mathrm{GA}_{3}$ might be due to the effect of enhanced photosynthetic efficiency, more dry matter accumulation in plants and better partitioning of photoassimilates and nutrients from leaves to the developing sink organs (Sharma and Singh 1990). Application of gibberellic acid significantly increased total soluble solids and reduced the titratable acidity in fruits. The results are in conformity with Ozguven et al., (2000). Montero et al., (1998) also observed enhanced anthocyanin content with the application of $\mathrm{GA}_{3}$ and it could be due to either direct or indirect involvement of $\mathrm{GA}_{3}$ in the synthesis of anthocyanin pigment or its precursor or by involving in the movement of its precursor.

Table.1 Effect of plant growth regulators on growth parameters of strawberry cv. Winter Dawn at 60 DAP

\begin{tabular}{|c|c|c|c|c|c|c|c|}
\hline Treatments & $\begin{array}{c}\text { Height } \\
\text { (cm) }\end{array}$ & $\begin{array}{c}\text { Spread } \\
\mathbf{( c m )}\end{array}$ & $\begin{array}{c}\text { Petiole } \\
\text { length } \\
\text { (cm) }\end{array}$ & $\begin{array}{c}\text { Number } \\
\text { of shoots } \\
\text { /plant }\end{array}$ & $\begin{array}{c}\text { Number } \\
\text { of leaves } \\
\text { /plant }\end{array}$ & $\begin{array}{c}\text { Leaf } \\
\text { area } \\
\left(\mathbf{c m}^{\mathbf{2}} \mathbf{n}\right.\end{array}$ & $\begin{array}{c}\text { Number of } \\
\text { runners } \\
\text { /plant }\end{array}$ \\
\hline $\mathbf{T}_{\mathbf{1}}$ & 16.37 & 35.62 & 15.43 & 19.07 & 22.28 & 119.58 & 4.95 \\
\hline $\mathbf{T}_{\mathbf{2}}$ & 18.33 & 37.30 & 16.47 & 20.89 & 23.29 & 121.12 & 5.23 \\
\hline $\mathbf{T}_{\mathbf{3}}$ & 14.13 & 31.08 & 11.63 & 17.29 & 18.74 & 116.09 & 3.95 \\
\hline $\mathbf{T}_{\mathbf{4}}$ & 15.15 & 34.31 & 12.36 & 17.45 & 19.95 & 117.35 & 4.34 \\
\hline $\mathbf{T}_{\mathbf{5}}$ & 10.95 & 28.57 & 9.81 & 15.01 & 14.27 & 103.99 & 2.36 \\
\hline $\mathbf{T}_{\mathbf{6}}$ & 10.71 & 27.83 & 9.24 & 14.21 & 13.19 & 101.58 & 2.76 \\
\hline $\mathbf{T}_{\mathbf{7}}$ & 12.69 & 30.28 & 13.72 & 16.65 & 16.34 & 110.70 & 3.41 \\
\hline $\mathbf{T}_{\mathbf{8}}$ & 13.52 & 32.86 & 14.37 & 17.85 & 17.12 & 112.53 & 3.62 \\
\hline $\mathbf{T}_{\mathbf{9}}$ & 11.84 & 28.39 & 10.44 & 16.23 & 15.93 & 98.31 & 1.85 \\
\hline $\mathbf{S E m} \mathbf{( \pm )}$ & 0.20 & 0.43 & 0.18 & 0.24 & 0.25 & 1.49 & 0.05 \\
\hline $\mathbf{C D}(\mathbf{5 \%})$ & 0.58 & 1.31 & 0.53 & 0.72 & 0.77 & 4.52 & 0.16 \\
\hline
\end{tabular}

*T $\mathrm{T}_{1}-\mathrm{GA}_{3} @ 20 \mathrm{ppm} ; \mathrm{T}_{2}-\mathrm{GA}_{3} @ 40 \mathrm{ppm} ; \mathrm{T}_{3}$-NAA @ $20 \mathrm{ppm} ; \mathrm{T}_{4}$-NAA @ 40 ppm; $\mathrm{T}_{5}$-Cycocel @ 500 ppm; $\mathrm{T}_{6}-$ Cycocel@750 ppm; T 7 -BA @ 25 ppm; $\mathrm{T}_{8}$-BA @ 50 ppm; $\mathrm{T}_{9}$-Control 
Table.2 Effect of plant growth regulators on flowering and fruit setting parameters of strawberry cv. Winter Dawn

\begin{tabular}{|c|c|c|c|c|c|c|}
\hline Treatment & $\begin{array}{c}\text { Duration } \\
\text { of } \\
\text { flowering } \\
\text { (Days) }\end{array}$ & $\begin{array}{c}\text { Duration } \\
\text { of fruit } \\
\text { setting } \\
\text { (Days) }\end{array}$ & $\begin{array}{c}\text { Duration } \\
\text { of fruit } \\
\text { maturity } \\
\text { (Days) }\end{array}$ & $\begin{array}{c}\text { Total } \\
\text { number of } \\
\text { flowers } \\
\text { /plant }\end{array}$ & $\begin{array}{c}\text { Total } \\
\text { number of } \\
\text { fruits } \\
\text { /plant }\end{array}$ & $\begin{array}{c}\text { Fruit set } \\
\text { \% }\end{array}$ \\
\hline $\mathbf{T}_{\mathbf{1}}$ & 36.88 & 5.79 & 18.79 & 25.41 & 19.28 & 75.78 \\
\hline $\mathbf{T}_{\mathbf{2}}$ & 36.10 & 5.70 & 18.45 & 27.16 & 21.23 & 78.05 \\
\hline $\mathbf{T}_{\mathbf{3}}$ & 39.05 & 5.37 & 17.54 & 24.13 & 17.76 & 73.49 \\
\hline $\mathbf{T}_{\mathbf{4}}$ & 38.41 & 5.32 & 17.33 & 24.90 & 18.51 & 74.36 \\
\hline $\mathbf{T}_{\mathbf{5}}$ & 31.77 & 4.50 & 15.72 & 22.46 & 14.88 & 66.25 \\
\hline $\mathbf{T}_{\mathbf{6}}$ & 29.36 & 4.29 & 15.55 & 23.24 & 15.75 & 67.69 \\
\hline $\mathbf{T}_{\mathbf{7}}$ & 38.60 & 6.09 & 19.31 & 23.74 & 16.58 & 69.78 \\
\hline $\mathbf{T}_{\mathbf{8}}$ & 38.23 & 5.86 & 18.20 & 24.38 & 17.37 & 71.21 \\
\hline $\mathbf{T}_{\mathbf{9}}$ & 43.13 & 6.55 & 21.68 & 19.04 & 12.08 & 63.44 \\
\hline $\mathbf{S E m}(\mathbf{+}$ & 0.52 & 0.08 & 0.18 & 0.32 & 0.23 & 0.95 \\
\hline $\mathbf{C D}(\mathbf{5} \boldsymbol{\%}$ & 1.58 & 0.24 & 0.54 & 0.95 & 0.70 & 2.88 \\
\hline
\end{tabular}

*T $\mathrm{T}_{1}-\mathrm{GA}_{3} @ 20$ ppm; $\mathrm{T}_{2}-\mathrm{GA}_{3} @ 40 \mathrm{ppm}$; $\mathrm{T}_{3}$-NAA @ 20 ppm; $\mathrm{T}_{4}$-NAA @ 40 ppm; $\mathrm{T}_{5}$-Cycocel @ 500 ppm; $\mathrm{T}_{6}-$ Cycocel@750 ppm; T7-BA@ 25 ppm; T

Table.3 Effect of plant growth regulators on physical parameters of fruit, yield and B:C ratio of strawberry cv. Winter Dawn

\begin{tabular}{|c|c|c|c|c|c|c|}
\hline Treatments & $\begin{array}{c}\text { Fruit } \\
\text { Volume } \\
\text { (cc) }\end{array}$ & $\begin{array}{c}\text { Length/ } \\
\text { Diameter } \\
\text { ratio }\end{array}$ & $\begin{array}{c}\text { Fruit } \\
\text { Weight }(\mathbf{g})\end{array}$ & $\begin{array}{c}\text { Fruit yield } \\
\text { (g/plant) }\end{array}$ & $\begin{array}{c}\text { Producti- } \\
\text { vity } \\
\text { (tonnes } \\
\text { /ha) }\end{array}$ & B:C ratio \\
\hline $\mathbf{T}_{\mathbf{1}}$ & 15.56 & 1.45 & 21.45 & 414.49 & 2.37 & $2.63: 1$ \\
\hline $\mathbf{T}_{\mathbf{2}}$ & 16.04 & 1.46 & 22.09 & 470.15 & 2.68 & $2.92: 1$ \\
\hline $\mathbf{T}_{\mathbf{3}}$ & 15.17 & 1.53 & 19.11 & 339.60 & 1.94 & $1.93: 1$ \\
\hline $\mathbf{T}_{\mathbf{4}}$ & 15.49 & 1.49 & 20.44 & 379.28 & 2.17 & $2.26: 1$ \\
\hline $\mathbf{T}_{\mathbf{5}}$ & 16.48 & 1.40 & 22.97 & 341.92 & 1.95 & $1.60: 1$ \\
\hline $\mathbf{T}_{\mathbf{6}}$ & 17.73 & 1.42 & 24.05 & 378.94 & 2.16 & $1.91: 1$ \\
\hline $\mathbf{T}_{\mathbf{7}}$ & 14.74 & 1.63 & 18.85 & 312.95 & 1.79 & $1.64: 1$ \\
\hline $\mathbf{T}_{\mathbf{8}}$ & 15.25 & 1.69 & 19.93 & 346.70 & 1.98 & $1.88: 1$ \\
\hline $\mathbf{T}_{\mathbf{9}}$ & 12.76 & 1.56 & 17.78 & 215.66 & 1.23 & $0.72: 1$ \\
\hline $\mathbf{S E m}(\mathbf{\pm})$ & 0.20 & 0.02 & 0.27 & 9.41 & 0.05 & -- \\
\hline $\mathbf{C D} \mathbf{( 5 \% )}$ & 0.62 & 0.06 & 0.81 & 28.45 & 0.16 & -- \\
\hline
\end{tabular}

* $\mathrm{T}_{1}-\mathrm{GA}_{3} @ 20 \mathrm{ppm} ; \mathrm{T}_{2}-\mathrm{GA}_{3} @ 40 \mathrm{ppm} ; \mathrm{T}_{3}$-NAA @ $20 \mathrm{ppm}$; $\mathrm{T}_{4}$-NAA @ $40 \mathrm{ppm} ; \mathrm{T}_{5}$-Cycocel @ $500 \mathrm{ppm} ; \mathrm{T}_{6}$ Cycocel@750 ppm; $\mathrm{T}_{7}$-BA @ 25 ppm; T $\mathrm{T}_{8}$-BA @ 50 ppm; $\mathrm{T}_{9}$-Control 
Table.4 Effect of plant growth regulators on chemical parameters of fruit quality of strawberry cv. Winter Dawn

\begin{tabular}{|c|c|c|c|c|c|c|c|}
\hline Treatments & $\begin{array}{c}\text { Total } \\
\text { Soluble } \\
\text { Solid } \\
\left({ }^{\circ} \text { Brix }\right)\end{array}$ & $\begin{array}{c}\text { Titrata- } \\
\text { ble } \\
\text { Acidity } \\
(\%)\end{array}$ & $\begin{array}{c}\text { TSS } \\
\text { /Acid } \\
\text { ratio }\end{array}$ & $\begin{array}{c}\text { Total } \\
\text { Sugar } \\
(\%)\end{array}$ & $\begin{array}{c}\text { Reduc- } \\
\text { ing } \\
\text { Sugar } \\
(\%)\end{array}$ & $\begin{array}{c}\text { Ascor- } \\
\text { bic Acid } \\
\text { Content } \\
\text { (mg/100 } \\
\text { g pulp) }\end{array}$ & $\begin{array}{l}\text { Antho- } \\
\text { cyanin } \\
\text { Content } \\
\text { (mg/100 } \\
\text { g pulp) }\end{array}$ \\
\hline$T_{1}$ & 6.10 & 0.63 & 10.05 & 5.30 & 4.12 & 55.75 & 63.43 \\
\hline $\mathbf{T}_{2}$ & 6.48 & 0.61 & 10.29 & 5.66 & 4.20 & 57.35 & 65.68 \\
\hline$T_{3}$ & 5.58 & 0.74 & 7.81 & 4.42 & 3.31 & 43.44 & 59.32 \\
\hline $\mathbf{T}_{4}$ & 5.43 & 0.72 & 7.76 & 4.87 & 3.38 & 45.00 & 61.94 \\
\hline $\mathbf{T}_{5}$ & 5.85 & 0.67 & 8.47 & 5.06 & 3.80 & 51.11 & 56.46 \\
\hline$T_{6}$ & 6.05 & 0.69 & 9.11 & 5.14 & 3.93 & 53.16 & 57.15 \\
\hline $\mathbf{T}_{7}$ & 5.31 & 0.75 & 7.08 & 4.17 & 3.10 & 42.90 & 58.28 \\
\hline $\mathbf{T}_{8}$ & 5.74 & 0.73 & 7.57 & 4.28 & 3.22 & 45.70 & 60.42 \\
\hline$T_{9}$ & 5.17 & 0.78 & 6.67 & 4.02 & 2.98 & 38.12 & 40.82 \\
\hline $\operatorname{SEm}( \pm)$ & 0.08 & 0.01 & 0.10 & 0.05 & 0.04 & 0.63 & 0.40 \\
\hline CD (5\%) & 0.23 & NS & 0.31 & 0.15 & 0.12 & 1.91 & 1.19 \\
\hline
\end{tabular}

* $\mathrm{T}_{1}-\mathrm{GA}_{3} @ 20 \mathrm{ppm} ; \mathrm{T}_{2}-\mathrm{GA}_{3} @ 40 \mathrm{ppm} ; \mathrm{T}_{3}-\mathrm{NAA} @ 20 \mathrm{ppm} ; \mathrm{T}_{4}-\mathrm{NAA} @ 40 \mathrm{ppm} ; \mathrm{T}_{5}$-Cycocel @ $500 \mathrm{ppm} ; \mathrm{T}_{6}-$ Cycocel@ 750 ppm; T-BA @ 25 ppm; $\mathrm{T}_{8}$-BA @ 50 ppm; T9-Control

\section{Benefit: cost ratio}

The treatment based on $\mathrm{GA}_{3} @ 40$ ppm has been found to be the most effective dose by giving highest net return mainly due to the production of larger and uniform sized fruits with better quality, which attracted the consumer and provided good market price. The application of $\mathrm{GA}_{3} @ 40$ ppm $\left(\mathrm{T}_{2}\right)$ came up with the greatest benefit:cost ratio (2.92: 1), which was followed by 2.63:1 due to $\mathrm{GA}_{3}$ @ $20 \mathrm{ppm}\left(\mathrm{T}_{1}\right)$ treatment.

In conclusion, on the basis of the results obtained in the present investigation, the inference can be drawn that different levels of plant growth regulators had considerable effect on growth, yield and qualitative parameters of strawberry. Among them, application of $\mathrm{GA}_{3} @ 40$ ppm at 15 and 30 DAP along with RDF (5 t FYM + 500 kg Vermicompost and NPK @ 100:80:100 $\mathrm{kg} / \mathrm{ha}$ ) had beneficial effects for improvement of plant growth, yield and fruit quality of strawberry cv. Winter Dawn with maximum $\mathrm{B}: \mathrm{C}$ ratioin the Gangetic alluvial region of West Bengal. Hence, $\mathrm{GA}_{3} @ 40$ ppm at 15 and 30 DAP can be recommended to the farmers of the Gangetic alluvial region of West Bengal for better plant growth, yield, quality and return of Strawberry cv. Winter Dawn.

\section{Acknowledgement}

The authors sincerely acknowledge the Department of Fruit Science, Bidhan Chandra Krishi Viswavidyalaya for providing support and facilities for successfully conducting this experiment.

\section{References}

Anonymous. 2018. Area and Production of Horticulture Crops - All India: 2017-18 (3rd Advance Est.). Indian Horticulture Database 2018, NHB, MoA, GoI, Gurgaon, Haryana, pp. 1. 
Anwar, M., Hafiz, Abdul Hana. 1990. Effect of different concentrations of gibberellic acid on the growth and yield of strawberry. Sarhad J. Agric., 6(1): 5759.

Basra, A. ed., 2000. Plant growth regulators in agriculture and horticulture: their role and commercial uses. CRC Press.

Gomez, K. A., Gomez, A. A. 1984. Statistical procedures for Agricultural Research, John Willey and Sons, New York.

Guttridge, C. G. and Thompson, P. A. 1959. Effect of gibberellic acid on length and number of epidermal cells in petioles of strawberry. Nature., 183(4655): 197.

Kumar, R., Bakshi, P., Srivastava, J. N. and Sravanan, S. 2012. Influence of plant growth regulators on growth, yield and quality of strawberry (Fragaria $\times$ ananassa Duch.) cv. Sweet Charlie.Asian J. Hort., 7(1): 40-43

Montero, T., Molla, E., Martin, C. M. A. and Lopez Andreu, F. J. 1998. Effect of $\mathrm{GA}_{3}$ on strawberry phenylalanine ammonia lyase and tyrosine ammonia lyase enzyme activities. J. Sci. Food Agric., 77(2): 230-234.

Ozguven, A. I., Yilmaz, C., Hietaranta, T. and Linna, M. 2000. The effect of $\mathrm{GA}_{3}$ and promalin on fruit quality of strawberry. Acta Hortic., 548: 216-219.

Rajesh, K., Manish, B. and Singh, D. B. 2012.
Influence of plant growth regulators on growth, yield and quality of strawberry (Fragaria $\times$ ananassa Duch.) under U.P. sub tropics. The Asian J. Hort., 7: 434-436.

Saima, Z., Sharma, A., Umar, I. and Wali, V. K. 2014. Effect of plant bio-regulators on vegetative growth, yield and quality of strawberry cv. Chandler. Afr. J. Agric. Res., 9(22): 1694-1699.

Sharma, V. P. and Sharma, R. R. 2004. The Strawberry, ICAR, New Delhi, India. pp. 106-109.

Sharma, V. P. and Singh, R. 1990. Growth and Fruiting behaviour of strawberry (Fragaria spp.) as affected by cloching and gibberellic acid treatments. Proceedings of the $11^{\text {th }}$ International Congress on the use of Plastics in Agriculture. New Delhi, India.141-149.

Singh, O. P. and Phogat, K. P. S. 1983. Effect of plant growth regulators on vegetative growth, yield and quality of strawberry (Fragaria sp.). Indian J. Hortic., 35: 207-211.

Turner, J. N. 1963. Application of gibberellic acid to strawberry plants at different stages of development. Nature.,197: 9596.

Wang, H., Cao, G. and Prior R. L. 1996. Total antioxidant capacity of fruits, J. Agric. Food Chem., 44: 701-705.

\section{How to cite this article:}

Tanushree Saha, Bikash Ghosh, Sanjit Debnath, Subhasis Kundu and Ajoy Bhattacharjee. 2019. Effect of Plant Growth Regulators on Growth, Yield and Quality of Strawberry (Fragaria $\times$ ananassa Duch.) cv. Winter Dawn in the Gangetic Alluvial Region of West Bengal, India. Int.J.Curr.Microbiol.App.Sci. 8(03): 1706-1712. doi: https://doi.org/10.20546/ijcmas.2019.803.198 